\title{
CREATIVE MARGINALIZATION OF GENDER: A DISCOURSE ANALYSIS OF ADVERTISEMENTS IN PAKISTANI NEWSPAPERS
}

\author{
Musarat YASMIN ${ }^{{ }^{*}}$, Farhat NASEEM ${ }^{2}$, Malik Hassan RAZA ${ }^{3}$ \\ ${ }^{1}$ University of Reading, Faculty of Arts, Humanities and Social Science, Department of English \\ Language and Applied Linguistics Reading, RG6 6AA, United Kingdom \\ ${ }^{2}$ University of Toronto, Munk School of Global Affairs, Faculty of Social Sciences, Ethnic, Immigration \\ and Pluralism Studies 1 Devonshire Place, Toronto, ON M5S2K7, Canada \\ ${ }^{3}$ University of Gujrat, Department of English, Gujrat, 57 000, Pakistan
}

Received 22 October 2017; accepted 12 July 2018

\begin{abstract}
Creative industries have been considered crucial to the economic well-being of any country. Besides the economy, the advertising industry has been investigated in West for its influence on the minds of its consumers. Pakistan has a diversity of culture and impact of creative industries on common people is not studied yet. The present study analyses the advertising discourse to explore gender construction through language and visuals in Pakistani print media. The sample includes four national English newspapers collected over a period of one month. An asymmetrical and stereotypical portrayal of women emerges from discourse analysis. Along with gender-specific language, images are constructed to render women marginalised as compared to men in Pakistani society. Results imply that creative industries have a potential to exert an ever-lasting impact on mass-mind but have become a tool in the hands of influential people.
\end{abstract}

Keywords: advertising, creative industries, discourse analysis, gender stereotyping, print media, visual analysis.

\section{Introduction}

Media is an integral part of daily life, and advertising is not only its powerful tool to provide an economic boost to media in particular and industries in general, but also can inform, promote, and penetrate into the human consciousness deeply. Its role in constructing gender stereotypes has been a focus of research for last more than five decades of research, resulting in a significant body of knowledge. A rise in efforts for equal opportunities for males and females drove a gradual change in not only in domestic settings but also at workplaces (Plakoyiannaki \& Zotos, 2009). Media and particularly advertising can be viewed as a primary and powerful tool for perpetuating gender stereotypes despite a compelling change observed in women participation in every field. The present study intends to explore how one gender is

*Corresponding author. E-mail: musaratalvi@hotmail.com 
constructed in comparison with the other, through the voices represented in print advertising. Researcher's interest lies in examining the semiotic structure of gender marginalisation mediated by linguistic aspects as at vocabulary or discourse level as discussed in detail by Gunther Kress and Theo van Leeuwen (1996). Through this analysis, the present study will inform the role of visual and textual discourse in creating stereotypes which affect men and women behaviour following generally established gendered roles in society.

\section{Advertising as a creative industry and gender stereotyping}

Advertising is the most influential tool of media. It can construct/destruct the minds of its consumers as Kenneth E. Clow and Donald Baack (2012) found common people bombarded with numerous advertising messages in one day. The potential of advertising is not limited to its dictionary definition as the activity to inform, attract and persuade public to buy a product (American Heritage Dictionary of the English Language, Merriam-Webster Online, Longman Business English Dictionary), instead it has far-reaching objectives which include changing consumption trends, boosting demands for goods, changing conduct patterns, and construct a positive public opinion on any targetted subject (Jokubauskas, 2003). These are non-profit objectives which may carry power to mould public opinion on any social aspect. Advertising has been considered "a bellwether of cultural trends, a mirror of social values, and a powerful, usually malevolent force that shapes those values" (Duffy, 1994, p. 5), thus, exhibits the strong impact it may exert. Research showed that advertising uses gender as one of its leading social resources (Mager \& Helgeson, 2011) and a review of past research showed the portrayal of women in advertising had been a theme of contentious debate since the 1960s (Zotos \& Tsichla, 2014).

Stereotyping involves marginalisation through negative judgement and reduction of a person into exaggerated traits (Barker, 1999). It does not only carry negative connotations but may render to expectations that restrict opportunities of a class or a person (Eisend, 2010). In case of gender stereotypes, as a consequence, women may go through reduced self-confidence and limited professional opportunities (Yasmin, Sohail, \& Mangrio, 2015). Gender stereotypes in the media have a well-established capability of determining socially acceptable ways to survive in society and role of advertising in invoking gender identities educate the readers/viewers about their roles (Goffman, 1987). A review of previous research (Lysonski, 1985; Kilbourne, 1999; Cortese, 2008; Lazar, 2006) shows advertising promotes gender inequality by fostering "sexism", which itself refers to constructing an image of women in an inferior way (Lysonski, 1985; Pollay, 1986; Plakoyiannaki \& Zotos, 2009). Though print advertisement has been excessively studied over more than a period of five decades (Zotos \& Tsichla, 2014) in various cultures, yet studies showed that documented stereotypes are far from being similar. Previous studies portrayed women in domestic roles only showing that the best place for woman is home (Ruggiero \& Weston, 1985) and in decorative roles (Mitchell \& Taylor, 1990; J. A. Wiles, Ch. R. Wiles, \& Tjernlund, 1995; Plakoyiannaki \& Zotos, 2009). Women are shown concerned with physical attractiveness whether or not the advertised product relates to sex. Numerous studies also showed a decrease in stereotyping as Michael L. Klassen, Cynthia R. Jasper and Anne Schwartz (1993), however, the decline 
in women's presence in traditional roles and a rise in equality portrayal did not make a difference as images of women still prevail for decorative purposes and non-active roles. A more subtle and indirect stereotyping has been reported recently as John Mager's and James G. Helgeson's (2011) and Yorgos C. Zotos' and Eirini Tsichla's (2014) review showed where women are continuously depicted as weak, dependent, and objects to please men.

\section{The theoretical foundation for analysis}

The present study followed the approach of critical discourse analysis (CDA) and conducted a multi-model analysis. It is contended that no single theory is consistent throughout CDA and it is not a single unitary framework (Dijk, 1993). CDA denotes to the analysis of any discourse, whether textual or visual, to uncover the relationship between discursive practices and social and cultural structures that produce a text which is apparently neutral but ideologically shaped by power relations (Fairclough, 1995, hence is not easy to bring to consciousness easily). The present study used Kress' and Leeuwen's (1996) model as an analytical tool to critique ideology in advertising discourse which is rich in the visual component.

Kress and Leeuwen (1996) claim that reading (or watching) a visual involves two types of participants: first, interactive participants, designer of that visual and the readers/viewers, interact during the process of reading, second, all the models represented in the visual. Both are engaged in three main meta-functions: representational, interactive and compositional. Representational structures show participant's representation in two main processes: narrative and conceptual. The narrative process involves actions or circumstances where actors are represented performing something. While conceptual process involves classification, analytical or symbolic process to represent participants. The interactive function relates to interaction among represented images, producers of these images and readers/viewers. As it centres on the position of readers/viewers and visual which influences the way visual is read, the present study focussed on interactive function more than other two. The visual resources in creating/maintaining social engagement include contact which can be interpreted as "demand" in case of represented participant's direct gaze and will be interpreted as "offer" in case of indirect gaze. Another resource is a social distance which creates a close and personal relation of turning image intimate or friend through close shots and impersonal relation through long shots. The size of frame used delivers a sense readers'/viewers' social closeness in relation to the image represented. Also, a frontal angle of a represented image creates a personal attitude towards readers/viewers while the use of oblique angle produces detachment from their world. In the same way, a vertical angle or image viewed from higher angle denotes power to the viewer than to participant represented. Lastly, use of modality markers provides a level of truthfulness to the represented participant. A higher degree of modality gives credibility to the visual image. While high modality markers include colour saturation/differentiation, contextualization with absence/full detail of background, representation with maximum abstraction/representation, image depth absence/maximum perspective, illumination with maximum/absence play of light and shade, maximum different degree of brightness/only two degrees of black and white and coding orientation as naturalistic/ technological/sensory/abstract. Modality will be higher with neutral colour saturation, maxi- 
mum diversity of colour range, detail of context and representation, deep perspective, the maximum play of light and shade and brightness whereas lower modality will be vice versa. Naturalistic visuals are, according to Kress and Leeuwen (1996), the dominant standard for visual modality in one's culture, hence can be measured as real whereas, sensory coding aims to provide sensory pleasure in the context of fashion. Scientific or technological orientation gives a blueprint of any description while abstract orientation works otherwise. Composition considers the informative structure where character placed on the top would carry more value as compared to one placed at the bottom. Moreover, the salience of character can be highlighted by size, colour, fronting.

Most of the studies of previous literature on analysing media discourse were conducted in Western and some in Eastern culture (Huang \& Lowry, 2015). Pakistan is a unique case due to its heritage of a diverse culture from various resources: impact of religion, post-colonial past and a shared history with India (Yasmin, Sohail, Sarkar, \& Hafeez, 2018; Yasmin \& Sohail, 2018a; Yasmin \& Sohail, 2018b). The present study intends to bring Pakistani media's role to light in subtly creating gendered identities. With its reliance on visual model, it may inform the readers and producers about the capacity of simple devices in (de)forming identities. The present study investigates the following problem.

How is gender constructed through language and visuals in English Pakistani newspapers?

\section{Research design}

Present research follows an interpretive paradigm to conduct a qualitative study. A sample of four English Pakistani newspapers was selected: The Nation, Dawn, Daily Times and The News. These newspapers were selected due to their publication all over the country and broader readership. The researcher selected two advertisements which appeared in all four newspapers: one with a male model and one with a female model. This selection was not random as the selected advertisements scored high in the earlier statistical analysis of visibility and both adverts were from same product and company whereas neutral advertisements were excluded due to focus on gender.

A qualitative multimodal discourse analysis was conducted to analyse text and visuals. Following CDA approach with Norman Fairclough's three dimensions of description, interpretation and explanation (Fairclough, 2001), the text was analysed at lexical and discourse level and it was found appropriate approach as print advertisements were richer in visual discourse than linguistic. Kress' and Leeuwen's (1996) model was employed to analyse visuals. Both analyses were aimed to deconstruct the interaction between advert and readers/viewers and the ways how one gender identities were created using these resources.

\section{Results and discussions}

Analysis of advertisements showed that visual language is not transparent but carries sociocultural orientation where men and women have a gendered identity. Following is a detailed analysis of two advertisements where textual and visual analysis is combined for recurring themes. 


\subsection{Cheetah (shoes for men)}

The advert shows an image of a man running wearing sports shirt, shorts and joggers of the company being advertised. The model captured in the photo is famous all-rounder cricketer Shahid Afridi who is famous for his batting as well as fast bowling (R. Khan, H. U. Khan, Faisal, K. Iqbal, \& M. Sh. Iqbal Malik, 2016). Behind him, there are six shadows of players from different fields, and they are distinct due to their different colours (see Figure 1).

His image serves different purposes. Firstly, the image is of a well-known player is used, and symbolic attributive process works well here. The surface message is that Afridi wears Cheetah joggers to run fast, so the product is a reason for his success. The readers get the message that if they want to be successful and famous, they must use these shoes.

A degree of readers'/viewers' involvement with visual was achieved through two contact strategies: first, the model was captured from the front, and he is looking directly at the readers/viewers, hence, engages them in social relation. Second, producer used Afridi's direct gaze to demand readers/viewers a required response also. It is further enhanced through the text in black colour in bold capital letters "LIVE THROUGH SPORT" where through imperative use of the verb "live", model demands readers/viewers to join him and lead a healthy and active life of a sportsperson with Cheetah joggers. The size of the frame can also interpret readers'/viewers' interaction with visual. A medium-long shot is taken to show a full figure that generally stands for a general social relationship, but the selection of popular cricketer's image gives it a more close relation with the audience. With a frontal angle, the image of Afridi suggests them that he has an equal power relation and maximum involvement with them, thus, he is a part of their world. Through this portrayal, the producer leads readers/ viewers to accept the model as well as product. Urdu word "Cheetah" was used to help readers identify their cultural similarity and familiarity with the product. The use of "Urdu" word denoted a concept of "ours" here. The readers may feel a sense of association on the first sight.

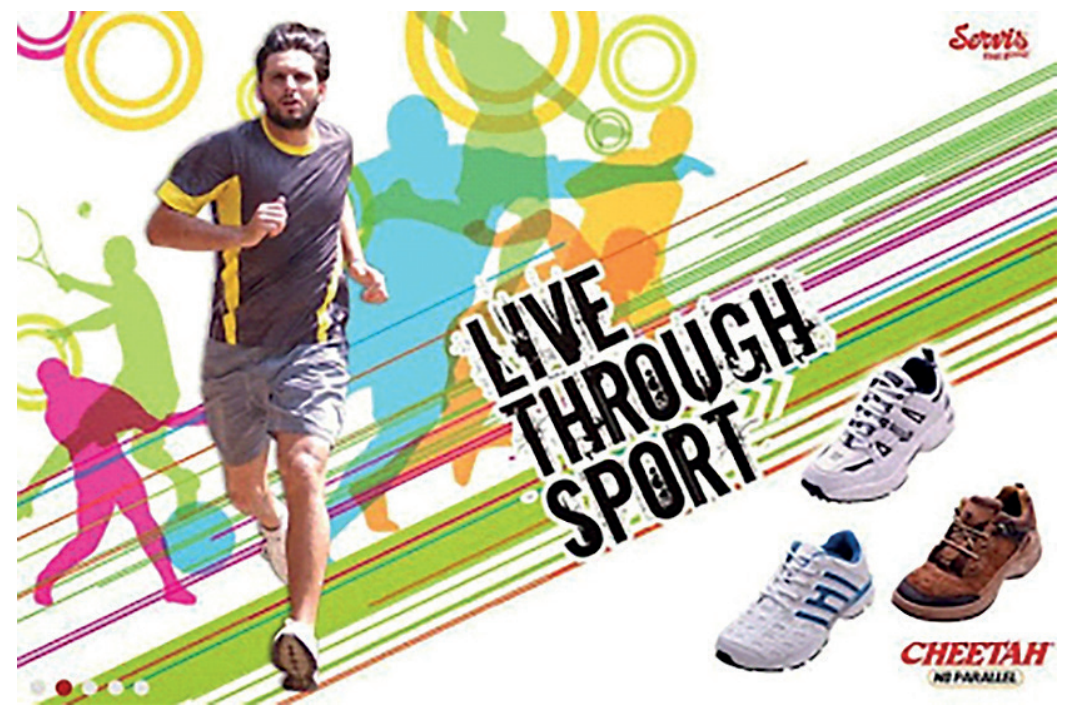

Figure 1. Advert of joggers Cheetah by Servis (source: The Nation, 2014) 
Through an abundant use of modal markers, producer tried to create the image and message close to reality to make readers/viewers believe. A variety of colours is used to create a sports-world in the background while the colours the model is wearing are distinct from background colours as the use of dark colour in Afridi's dress not only enhances his image graphically but also gives him a real touch in contrast with light colours of shadows. Moreover, the image shows the body in motion with minute details of flying hair, stretched muscles, which are also clear from wrinkles on the sports dress. The use of green colour denotes to the field of player and use of sunlight and shade on player's image makes it more real as usually matches are held in the daytime. Product image and company logo have a white background which is perhaps to break the colour stream and avoid to get it lost in other images.

Whereas compositional meaning is concerned, the model was represented on the left side as something "known" while the image of shoes was on right side directing the readers/viewers to new information. Also, the image on the left leads them to understand and respond to new information on the right side.

Advert addresses specific target audience; the readers/viewers are positioned as male through the use of various strategies. First, the image of male sportsperson confirms this supposition. It can be inferred from the image that that running or the field of sports is a norm for male only. Also, the skills and physical abilities required for a sportsperson depend on biological difference. Afridi's image invokes the physiological differences to justify women's secondary status in active sporting life (Lorber, 1993). Moreover, the player is in the active position, exhibiting power and strength of body, a stereotypical image of man which, perhaps, cannot be expressed through the image of a woman player as the phrase "No Parallel" also shows. In sports, categories of athletes are determined on the basis of chromosomes, despite the fact that some women may compete with some men in many sports. This is how physiology has influenced the rules of competition. In point of fact, the overall position of men and women players is more political and ideological matter and it has more to do with cultural rules than with their physical abilities. Second, despite the fact that 'Cheetah' is the fastest land mammal whose body is aerodynamic for fast speed and it stands for physical strength and energy, in Urdu, the word "Cheetah" symbolises male animal and is usually used for male courageous persons. Hence, it delimits the product to male readers/viewers only. "Cheetah" has been used by other agencies also to denote fast speed as New York Racing Association to provide an explicit source of motivation to its athletes (Lloyd \& Woodside, 2013).

\subsection{Liza (shoes for women)}

On the contrary of male-directed advert Cheetah, the other advert by the same shoe company gives an entirely different picture (as shown in Figure 2).

Three female models are shown talking, laughing and enjoying cycling carelessly. Models are placed in half of the visual with dark background whereas other half is occupied with product image, the title of the product and company logo with white background. The background shows graphic flowers in monochromatic tones that serves as a unifying element for two parts. 


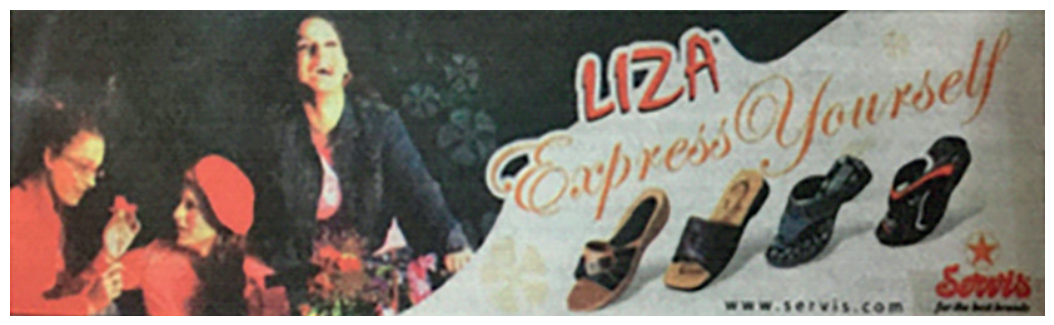

Figure 2. Advert of joggers Liza by service (source: The Nation, 2014)

Whereas position of readers/viewers are concerned, the present advert also drew upon models selected randomly as none of them is well-known to the ordinary reader. Images of two models have oblique angle while the third model is captured with the front angle but, interestingly, none of them is made engaged with readers/viewers with a direct gaze. It can be assumed that producer opted to offer the represented participants in an impersonal way as "though they were specimens in a display case" (Kress \& Leeuwen, 1996, p. 124).

A medium close shot of models cutting at waist stands for social relation where readers/ viewers feel some link and engagement with the image. However, the small size of images implies a long shot that distances readers from represented participants to indicate that models are not from this world, turning the relationship into more public and impersonal. A shot of models from a higher angle gives readers/viewers a higher degree of power over-represented participants. Hence, these two devices of frame and attitude strengthen the effort of the producer to render images away from readers'/viewers' world, i.e. presented for contemplation only and not to be taken seriously.

Use of modality markers constructs female models in such a way to make the readers believe in constructed reality. All three models have applied makeup and are dressed brightly. Use of red and green colour in contrast with black background makes them live human and enhances their image prominently. The first impression confirms the stereotype image of women who have nothing serious and significant to do in life which produces the notion that they should not be taken seriously. Use of artificial light and shade, instead of daylight, also gives them an impact of superficiality. Two of the models are shown talking about flowers which symbolise beauty, delicacy and soft feel. The images of these two models show a happy, light and carefree mood. They are wearing red colour which symbolises intensity of emotions and lively nature. It gives the message to the readers that if they want to enjoy life, they should wear these light, glamorous, and comfortable pair of flee-flaps in contrast with the message that Cheetah gives - "to be successful". A clear message is generated here that women are less of worth as compared to men as was found by earlier studies (Lysonski, 1985; Pollay, 1986; Plakoyiannaki \& Zotos, 2009).

The words "Express Yourself' under the title Liza makes the readers read as "Liza", "Express Yourself" which gives the sounds a suggestion rather than a demand. The phrase "Express Yourself' signifies that women can express them only through enjoying life. The product, on the other hand, could show them expressing abilities. The English word "Liza" denotes femininity, glamour and a Western touch which is further enhanced with a curly font. 
Similar to earlier advert, the present advert also used the same strategy of presenting information from left to right where models are supposed to lead to new and required information, i.e. buying product. However, this advert used female models who might not be familiar to the target audience, may not serve the intended purpose well. Here the use of two distinct backgrounds might enhance the product which, otherwise, might have lost the effect if the producer had kept one black background for the whole visual.

Present advert addresses an audience who must be female. The producer used few strategies to meet his intention: use of female participants, and curl font style and red colour for the text as compared to the simple Arial font in black colour used earlier in "LIVE THROUGH SPORT".

Unlike the previous advert, this advert does not show them wearing the product, and one finds no direct connection between the images and the product. It instead strengthens the stereotype notion that images of women are used to sell the product, a finding articulated by Mager's and Helgeson's (2011) also. This notion is observed in other advertisements also where the image of women is used in the advertisement of different products which are used by men and women both. Here the preference for the image of women instead of men turns the women turned into marketing commodities.

\section{Conclusions}

The present study analysed print advertisements to explore the role of media as creative industry and results showed explicitly that advertising genre in media has a high potential in creating gendered identities in quite a subtle way which a surface reading may not point out. Textual and semiotic aspects are manipulated to produce an intended message which is delivered successfully to consumers' minds. The male model was made acceptable, close to readers/viewers through visual devices and use of mother tongue. A strong, active and successful image of a male was made real with appropriate use of modality. Contrary to male representation, female models were portrayed with such contact devices that they seemed more impersonal and far from readers' actual world. An image of non-serious and of less worth was made real with apt modal markers. Hence, a simple and straightforward message of marketing of a product was found loaded with stereotypical portrayal of men and women where women were marginalised to insignificant, non-serious, and worthless commodities only.

It is highly significant to uncover the impact of apparently simple marketing tools on the minds of consumers, particularly women. Future endeavours may centre on the influence of textual and visual devices on the psychology of female readers as well as on general male readers and their following treatment of women afterwards. However, researcher argues here that creative industry of media and particularly its genre of advertising can be utilised to construct a positive image of women in Pakistani society. The same devices can be used to create an active and purposeful image of women which would not only boost their confidence as well as their contribution to society. 


\section{References}

Barker, Ch. (1999). Television, globalization and cultural identities. Series: Issues in Cultural and Media Studies. Buckingham: Open University Press.

Clow, K. E., \& Baack, D. (2012). Integrated advertising, promotion, and marketing communications. Upper Saddle River, NJ: Prentice Hall, Inc.

Cortese, A. J. (2008). Provocateur: images of women and minorities in advertising. Lanham: Rowman \& Littlefield Publishers, Inc.

Dijk, van T. A. (1993). Principles of critical discourse analysis. Discourse \& Society, 4(2), 249-283. https://doi.org/10.1177/0957926593004002006

Duffy, M. (1994). Body of evidence: studying women and advertising. In L. Manca, A. Manca, \& W. Scarlato (Eds.), Gender \& utopia in advertising: a critical reader (pp. 5-30). Lisle, IL: Procopian Press.

Eisend, M. (2010). A meta-analysis of gender roles in advertising. Journal of the Academy of Marketing Science, 38(4), 418-440. https://doi.org/10.1007/s11747-009-0181-x

Fairclough, N. (1995). Critical discourse analysis: the critical study of language. London: Addison Wesley Publishing Company.

Fairclough, N. (2001). Language and power. Harlow: Pearson Education Limited.

Goffman, E. (1987). Gender advertisements. New York: Harper Torchbooks.

Huang, Y., \& Lowry, D. T. (2015). Toward better gender equality? Portrayals of advertising models' occupational status in Chinese magazines. Journal of International Consumer Marketing, 27(1), 69-83. https://doi.org/10.1080/08961530.2014.967904

Jokubauskas, D. (2003). Reklama ir jos poveikis vartotojui. Vilnius: InSpe.

Khan, R., Khan, H. U., Faisal, M. Sh., Iqbal, K., \& Iqbal Malik, M. Sh. (2016). An analysis of Twitter users of Pakistan. International Journal of Computer Science and Information Security, 14(8), 855-864.

Kilbourne, J. (1999). Deadly persuasion: why women and girls must fight the addictive power of advertising. New York, NY: Free Press.

Klassen, M. L., Jasper, C. R., \& Schwartz, A. M. (1993). Men and women: images of their relationships in magazine advertisements. Journal of Advertising Research, 33(2), 30-39.

Kress, G., \& Leeuwen, van Th. (1996). Reading images: the grammar of visual design. London and New York: Routledge.

Lazar, M. M. (2006). "Discover the power of femininity!" analysing global "Power femininity" in local advertising. Feminist Media Studies, 6(4), 505-517. https://doi.org/10.1080/14680770600990002

Lloyd, S., \& Woodside, A. G. (2013). Animals, archetypes, and advertising $\left(\mathrm{a}^{3}\right)$ : the theory and the practice of customer brand symbolism. Journal of Marketing Management, 29(1-2), 5-25. https://doi.org/10.1080/0267257X.2013.765498

Lorber, J. (1993). Believing is seeing: biology as ideology. Gender and Society, 7(4), 568-581. https://doi.org/10.1177/089124393007004006

Lysonski, S. (1985). Role portrayals in British magazine advertisement. European Journal of Marketing, 19(7), 37-55. https://doi.org/10.1108/EUM0000000004724

Mager, J., \& Helgeson, J. G. (2011). Fifty years of advertising images: some changing perspectives on role portrayals along with enduring consistencies. Sex Roles, 64(3-4), 238-252. https://doi.org/10.1007/s11199-010-9782-6

Mitchell, P. C. N., \& Taylor, W. (1990). Polarising trends in female role portrayals in UK advertising. European Journal of Marketing, 24(5), 41-49. https://doi.org/10.1108/03090569010003482

The Nation. (2014). Nawaiwaqt group. Retrieved from https://nation.com.pk/nawaiwaqt-group 
Plakoyiannaki, E., \& Zotos, Y. (2009). Female role stereotypes in print advertising: identifying associations with magazine and product categories. European Journal of Marketing, 43(11-12), 1411-1434. https://doi.org/10.1108/03090560910989966

Pollay, R. W. (1986). The distorted mirror: reflections on the unintended consequences of advertising. Journal of Marketing, 50, 18-36. https://doi.org/10.2307/1251597

Ruggiero, J. A., \& Weston, L. C. (1985). Work options for women in women's magazines: the medium and the message. Sex Roles, 12(5-6), 535-547. https://doi.org/10.1007/BF00288174

Wiles, J. A., Wiles, Ch. R., \& Tjernlund, A. (1995). A comparison of gender role portrayals in magazine advertising: the Netherlands, Sweden and the USA. European Journal of Marketing, 29(11), 35-49. https://doi.org/10.1108/03090569510100696

Yasmin, M., Sohail, A., \& Mangrio, R. A. (2015). Myths broken or sustained: representation of women victims in Pakistani media. Open Journal of Social Sciences, 3, 209-219. https://doi.org/10.4236/jss.2015.37033

Yasmin, M., \& Sohail, A. (2018a). Socio-cultural barriers in promoting learner autonomy in Pakistani universities: English teachers' beliefs. Cogent Education, 5(1) 1-12. https://doi.org/10.1080/2331186X.2018.1501888

Yasmin, M., \& Sohail, A. (2018a). A creative alliance between learner autonomy and English language learning: Pakistani university teachers' beliefs. Creativity Studies, 11(1), 1-9. https://doi.org/10.3846/23450479.2017.1406874

Yasmin, M., Sohail, A., Sarkar, M., \& Hafeez, R. (2017). Creative methods in transforming education using human resources. Creativity Studies, 10(2), 145-158. https://doi.org/10.3846/23450479.2017.1365778

Zotos, Y. C., \& Tsichla, E. (2014). Female stereotypes in print advertising: a retrospective analysis. Procedia: Social and Behavioral Sciences, 148, 446-454. https://doi.org/10.1016/j.sbspro.2014.07.064

\title{
KŪRYBINIS LYTIES MARGINALIZAVIMAS: REKLAMOS DISKURSO PAKISTANO LAIKRAŠČIUOSE ANALIZE்
}

\author{
Musarat YASMIN, Farhat NASEEM, Malik Hassan RAZA
}

\section{Santrauka}

Kūrybinès industrijos traktuojamos kaip esminès bet kurios šalies ekonominei gerovei. Be ekonomikos, reklamos industrija Vakaruose tyrinèjama dèl jos įtakos vartotojų suvokimui. Pakistano kultūros ịvairovè ir kūrybinių industrijų ịtaka eiliniams žmonèms dar nèra ištirta. Šiame tyrime analizuojamas reklamos diskursas siekiant paaiškinti lyties konstravimą, pasitelkiant kalbą ir vizualinę medžiagą Pakistano spaudos medijose. Pavyzdyje pasitelkiami keturi angliški laikraščiai, išleisti vieno mėnesio laikotarpiu. Diskurso analizès rezultatas - asimetriškas ir stereotipinis moterų portretas. Kartu su lyčiai būdinga kalba konstruojami įvaizdžiai siekiant marginalizuoti moteris, kad būtų galima jas palyginti su vyrais Pakistano visuomeneje. Rezultatai atskleidžia, kad kūrybinès industrijos gali daryti nuolatinę ịtaką masių mąstymui, tačiau yra tapusios priemone įtakingų žmonių rankose.

Reikšminiai žodžiai: reklama, kūrybinès industrijos, diskurso analizè, lyties stereotipizavimas, spaudos medijos, vizualinè analizè. 